NOTE

\title{
New Materials Which Cure without Shrinkage. Preparation and Polymerization of Diurethanes Containing Bicyclic Ortho Ester Structure
}

\author{
Takeshi ENDO, ${ }^{*}$ Makoto OKAWARA, ${ }^{*}$ and W. J. BAILEY** \\ *Research Laboratory of Resources Utilization, \\ Tokyo Institute of Technology, \\ Nagatsuta-cho, Midori-ku, Yokohama 227, Japan \\ **Department of Chemistry, University of Maryland, \\ College Park, MD 20742, USA
}

(Received July 15, 1982)

\begin{abstract}
KEY WORDS Diisocyanate / Diurethane / Bicyclic Ortho Ester / Cationic Polymerization / Expansion Polymerization / Crosslinked Polymer /
\end{abstract}

For a number of industrial applications such as strain free composites, potting resins, precision coating, high strength adhesives, prestressed casting, and dental filling, it is highly desirable to have monomers that show nearly zero shrinkage or expansion on polymerization.

In our preceding papers, it was reported ${ }^{1-4}$ that the polymerization of spiro ortho esters and spiro ortho carbonates occurs with essentially zero shrinkage or very little expansion. Recently, we reported $^{5-6}$ that bicyclic ortho esters containing alkyl, hydroxymethyl, and urethane groups can be polymerized with Lewis acids to undergo expansion on polymerization.<smiles>[R]C1OCC([R])(COC)CO1</smiles><smiles>[R]OCC([R])(CC)CO</smiles>

$\mathrm{R}=\mathrm{Me}, \mathrm{Et}$

$\mathrm{R}^{\prime}=\mathrm{Me}, \mathrm{Et}, \mathrm{CH}_{2} \mathrm{OH}, \mathrm{CH}_{2} \mathrm{OCONHR}{ }^{\prime \prime}$

The present paper describes the preparation and volume change during the crosslinking of diurethanes containing bicyclic ortho ester structure which result from the reaction of the corresponding diisocyanates and 1-alkyl-4-hydroxymethyl- 2,6,7trioxabicyclo[2.2.2]octanes.

\section{EXPERIMENTAL}

\section{Materials}

Diisocyanates, dibutyl tin dilaurate, pentaerythritol, triethyl orthoacetate, and triethyl orthopropionate were of commercial grade. All solvents used in this study were purified by the usual proce- dure. 1-Ethyl-4-hydroxymethyl-2,6,7-trioxabicyclo[2.2.2]octane (I) and 1-methyl-4-hydroxymethyl2,6,7-trioxabicyclo[2.2.2] octane (II) were prepared by the method reported previously. ${ }^{6)}$

Preparation of Diurethanes Containing Bicyclic Ortho Ester (III-VIII) Typical Procedure; Preparation of III by the reaction of hexamethylene diisocyanate and $\mathbf{I}$

A solution containing $8.4 \mathrm{~g}(0.05 \mathrm{~mol})$ of hexamethylene diisocyanate, $17.2 \mathrm{~g}(0.1 \mathrm{~mol})$ of $\mathbf{I}$, and $0.7 \mathrm{~g}$ of dibutyltin dilaurate in $70 \mathrm{~cm}^{3}$ of toluene was heated and maintained at $70^{\circ} \mathrm{C}$ for $6 \mathrm{~h}$. After the reaction, toluene was evaporated under reduced 
pressure and the residue was recrystallized from ethyl acetate- $n$-hexane to give $21 \mathrm{~g}(82 \%)$ of III. IR $3300(\mathrm{NH}), 1750 \mathrm{~cm}^{-1}(\mathrm{C}=\mathrm{O}) ;{ }^{1} \mathrm{H}$ NMR $\left(\mathrm{CDCl}_{3}\right)$ $\delta 0.93-1.70\left[18 \mathrm{H}, \mathrm{m},\left(\mathrm{CH}_{2}\right)_{4}\right.$ and $\left.2 \mathrm{CH}_{2} \mathrm{CH}_{3}\right], 3.11$ $\left(4 \mathrm{H}, \mathrm{t}, 2 \mathrm{CH}_{2}\right), 3.83\left(4 \mathrm{H}, \mathrm{s}, 2 \mathrm{OCH}_{2}\right), 3.96(12 \mathrm{H}, \mathrm{s}$, $\left.6 \mathrm{OCH}_{2}\right)$, and $4.80 \mathrm{ppm}(2 \mathrm{H}, \mathrm{s}, \mathrm{NH})$.

Anal. Calcd for $\mathrm{C}_{24} \mathrm{H}_{40} \mathrm{O}_{10} \mathrm{~N}_{2}: \mathrm{C}, 55.80 \% ; \mathrm{H}$, $7.81 \%$; N, $5.42 \%$. Found: C, $55.82 \%, \mathrm{H}, 7.87 \%$, N, $5.41 \%$.

IV-VIII were also prepared in a similar way.

IV, yield $80 \%$; mp $141^{\circ} \mathrm{C}$ (toluene); IR 3300 (NH), $1750 \mathrm{~cm}^{-1}(\mathrm{C}=\mathrm{O}) ;{ }^{1} \mathrm{H}$ NMR $\left(\mathrm{CDCl}_{3}\right)$ $\delta 0.9-1.7\left[14 \mathrm{H}, \mathrm{m},\left(\mathrm{CH}_{2}\right)_{4}\right.$ and $\left.2 \mathrm{CH}_{3}\right], 3.12(4 \mathrm{H}, \mathrm{m}$, $\left.2 \mathrm{CH}_{2}\right), 3.84\left(4 \mathrm{H}, \mathrm{s}, 2 \mathrm{OCH}_{2}\right)$, and $3.97 \mathrm{ppm}(12 \mathrm{H}, \mathrm{s}$, $6 \mathrm{OCH}_{2}$ ).

Anal. Calcd for $\mathrm{C}_{22} \mathrm{H}_{36} \mathrm{O}_{10} \mathrm{~N}_{2}: \mathrm{C}, 54.09 \% ; \mathrm{H}$, $7.43 \%$; N, $5.73 \%$. Found: C, $54.12 \%$; H, $7.51 \%$; N, $5.70 \%$.

V, yield $90 \% ; \quad \mathrm{mp} \quad 104-107^{\circ} \mathrm{C} \quad\left(\mathrm{CH}_{2} \mathrm{Cl}_{2}-n-\right.$ hexane); IR $3350(\mathrm{NH}), 1755 \mathrm{~cm}^{-1}(\mathrm{C}=\mathrm{O}) ;{ }^{1} \mathrm{H}$ NMR $\left(\mathrm{CDCl}_{3}\right) \delta 0.7-2.2\left[30 \mathrm{H}, \mathrm{m},\left(\mathrm{C}_{6} \mathrm{H}_{9}\right)_{2} \mathrm{CH}_{2}\right.$ and $2 \mathrm{CH}_{2} \mathrm{CH}_{3}$ ], $3.86\left(4 \mathrm{H}, \mathrm{s}, 2 \mathrm{OCH}_{2}\right), 3.98(12 \mathrm{H}, \mathrm{s}$, $\left.6 \mathrm{OCH}_{2}\right)$, and $4.60 \mathrm{ppm}(2 \mathrm{H}, \mathrm{s}, 2 \mathrm{NH})$.

Anal. Calcd for $\mathrm{C}_{31} \mathrm{H}_{50} \mathrm{O}_{10} \mathrm{~N}_{2}: \mathrm{C}, 60.96 \% ; \mathrm{H}$, $8.25 \%$; N, $4.59 \%$. Found: C, $60.92 \%$; H, $8.30 \%$; N, $4.55 \%$.

VI, yield $92 \%$; mp $168^{\circ} \mathrm{C}\left(\mathrm{CH}_{2} \mathrm{Cl}_{2}-n\right.$-hexane); IR $3320(\mathrm{NH}), 1755 \mathrm{~cm}^{-1}(\mathrm{C}=\mathrm{O}) ;{ }^{1} \mathrm{H}$ NMR $\left(\mathrm{CDCl}_{3}\right)$ $\delta 0.93\left(6 \mathrm{H}, \mathrm{t}, 2 \mathrm{CH}_{3}\right), 1.68\left(4 \mathrm{H}, \mathrm{q}, 2 \mathrm{CH}_{2}\right), 3.83(2 \mathrm{H}$, $\left.\mathrm{s}, \mathrm{CH}_{2}\right), 3.90\left(4 \mathrm{H}, \mathrm{s}, 2 \mathrm{OCH}_{2}\right), 3.97\left(12 \mathrm{H}, \mathrm{s}, 6 \mathrm{OCH}_{2}\right)$, and $7.67 \mathrm{ppm}\left(8 \mathrm{H}, \mathrm{m}, 2 \mathrm{C}_{6} \mathrm{H}_{4}\right)$.

Anal. Calcd for $\mathrm{C}_{31} \mathrm{H}_{38} \mathrm{O}_{10} \mathrm{~N}_{2}: \mathrm{C}, 62.19 \% ; \mathrm{H}$, $6.40 \%$; N, $4.68 \%$. Found: C, $62.15 \%$; H, $6.43 \%$; N, $4.65 \%$.

VII, yield $84 \%$; mp $114-115^{\circ} \mathrm{C}\left(\mathrm{CH}_{2} \mathrm{Cl}_{2}-n\right.$ hexane); IR $3350(\mathrm{NH}), 1750 \mathrm{~cm}^{-1}(\mathrm{C}=\mathrm{O}) ;{ }^{1} \mathrm{H}$ NMR $\left(\mathrm{CDCl}_{3}\right) \delta 0.93\left(6 \mathrm{H}, \mathrm{t}, 2 \mathrm{CH}_{3}\right), 1.70(4 \mathrm{H}, \mathrm{q}$, $\left.2 \mathrm{CH}_{2}\right), 2.16\left(3 \mathrm{H}, \mathrm{s}, \mathrm{CH}_{3}\right), 3.90\left(4 \mathrm{H}, \mathrm{s}, 2 \mathrm{CH}_{2}\right), 3.99$ $\left(12 \mathrm{H}, \mathrm{s}, 6 \mathrm{OCH}_{2}\right), 4.80(2 \mathrm{H}, \mathrm{s}, \mathrm{NH})$, and $6.4-7.8$ ppm $\left(3 \mathrm{H}, \mathrm{m}, \mathrm{C}_{6} \mathrm{H}_{3}\right)$.

Anal. Calcd for $\mathrm{C}_{25} \mathrm{H}_{34} \mathrm{O}_{10} \mathrm{~N}_{2}: \mathrm{C}, 57.46 \% ; \mathrm{H}$, $6.56 \%$; N, 5.36\%. Found: C, $57.42 \%$; H, $6.59 \%$; N, $5.31 \%$.

VIII, yield $78 \% ; \quad \mathrm{mp} \quad 88-91^{\circ} \mathrm{C} \quad\left(\mathrm{CH}_{2} \mathrm{Cl}_{2}-n\right.$ hexane); IR $3320(\mathrm{NH}), 1755 \mathrm{~cm}^{-1}(\mathrm{C}=\mathrm{O}) ;{ }^{1} \mathrm{H}$ NMR $\left(\mathrm{CDCl}_{3}\right) \delta 0.94-1.07\left(22 \mathrm{H}, \mathrm{m}, 5 \mathrm{CH}_{3}\right.$ and $\left.\mathrm{C}_{6} \mathrm{H}_{7}\right), 1.70\left(4 \mathrm{H}, \mathrm{q}, 2 \mathrm{CH}_{2}\right), 2.89\left(2 \mathrm{H}, \mathrm{s}, \mathrm{CH}_{2}\right), 3.86$ $\left(4 \mathrm{H}, \mathrm{s}, 2 \mathrm{OCH}_{2}\right)$, and $3.97 \mathrm{ppm}\left(12 \mathrm{H}, \mathrm{s}, 6 \mathrm{OCH}_{2}\right)$.

Anal. Calcd for $\mathrm{C}_{28} \mathrm{H}_{46} \mathrm{O}_{10} \mathrm{~N}_{2}: \mathrm{C}, 58.93 \% ; \mathrm{H}$, $8.13 \%$; N, $4.91 \%$. Found: C, $58.90 \%$; H, $8.15 \%$; N,
$4.89 \%$

\section{Polymerization of III-VIII}

Polymerization was carried out in sealed tubes. III-VIII were polymerized in the presence of $\mathrm{BF}_{3} \mathrm{OEt}_{2}(3.0 \mathrm{~mol} \%$ for the monomer) used as a catalyst in bulk at $130^{\circ} \mathrm{C}$ to give insoluble polymers quantitatively in all cases. The obtained crosslinked polymers were purified by washing with acetone three times.

\section{Measurement of Density}

Transparent disks were prepared from $40 \mathrm{mg}$ of the polymers by pressing at $200 \mathrm{~kg} \mathrm{~cm}^{-2}$ and degassing in vacuo. The density of the obtained disk was measured using an apparatus for density measurement according to the density gradient tube method (Shibayama Kagaku Co.) at $25^{\circ} \mathrm{C}$. The measurement was carried out using other disks of the same polymer three times. The reproducibility was extremely good $( \pm$ less than 0.001$)$.

\section{RESULTS AND DISCUSSION}

\section{Preparation of Diurethanes Containing Bicyclic} Ortho Ester Structure

Bicyclic ortho esters, 1-ethyl-4-hydroxymethyl2,6,7-trioxabicyclo[2.2.2]octane (I) and 1-methyl4-hydroxymethyl-2,6,7-trioxabicyclo[2.2.2]octane (II) were prepared by the reaction of penta-

Table I. Synthesis of diurethanes containing bicyclic ortho ester structure

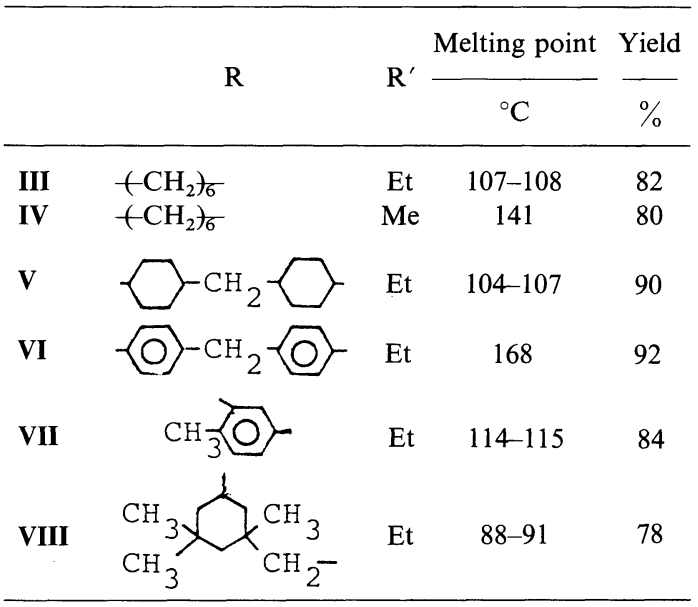


erythritol with triethyl orthopropionate or triethyl orthoacetate, respectively, according to the method reported by us. ${ }^{6}$

By the reaction of diisocyanates with I or II by use of dibutyltin dilaurate as a catalyst, the cor- responding diurethanes (III-VIII) having bicyclic ortho ester structures were obtained. The monomer structures were confirmed by IR, NMR, and elemental analyses, as described in experimental parts. The results are indicated in Table I.

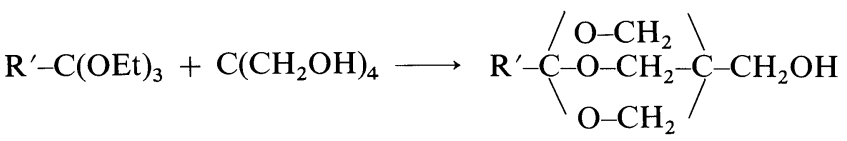

$$
\begin{aligned}
& \mathrm{I}, \mathrm{R}^{\prime}=\mathrm{Et} \\
& \text { II, } \mathrm{R}^{\prime}=\mathrm{Me}
\end{aligned}
$$

$2 \mathrm{I}$ or $2 \mathrm{II}+\mathrm{OCN}-\mathrm{R}-\mathrm{NCO}$

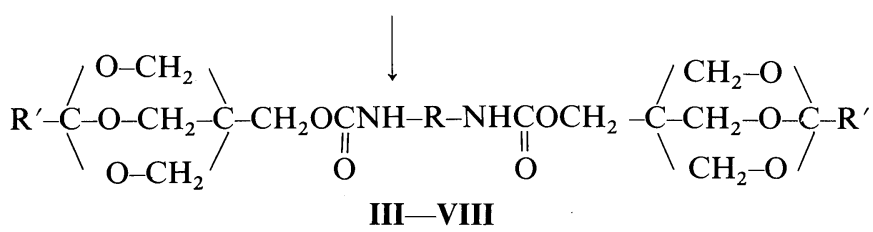

Polymerization and Volume Change on Polymer- Lewis acids to give polyethers containing ester ization of Diurethane Monomers

The bicyclic ortho esters were polymerized with groups in the side chain, as formulated in the following equation. ${ }^{5}$

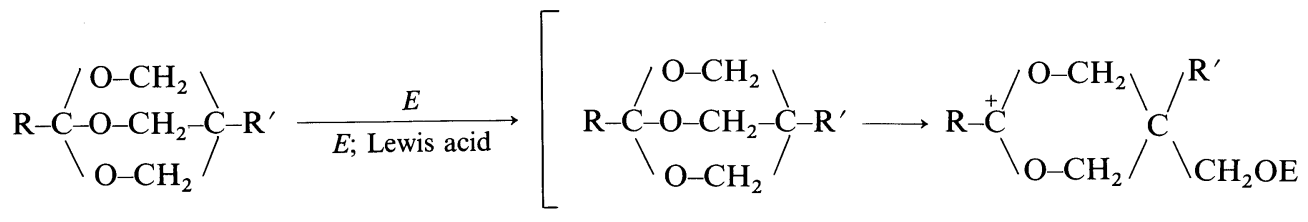<smiles>[R]C(=O)OCC([R])(CO)COC</smiles><smiles>[R]OCC([R])(CCCC)COC(=O)O</smiles>

The monomers (III-VIII) were polymerized at $150^{\circ} \mathrm{C}$ using $\mathrm{BF}_{3} \mathrm{OEt}_{2}(2 \mathrm{~mol} \%)$ as a catalyst to give the corresponding crosslinked polymers respectively by the ring-opening reaction of the bicyclic ortho esters described above. The infrared spectra of the obtained polymers showed the characteristic carbonyl absorptions (ester, 1720-1730 $\mathrm{cm}^{-1}$; urethane, $1740-1755 \mathrm{~cm}^{-1}$ ) and an absorption attributable to the ether linkage $\left(1250,1110 \mathrm{~cm}^{-1}\right)$.

The density of the monomers and purified crosslinked polymers was measured at $25^{\circ} \mathrm{C}$ and are shown in Table II. When the density of the polymers was compared with that of the corresponding monomers respectively, the volume change with

Table II. Density of monomers and polymers, and volume change with crosslinking of diurethanes containing bicyclic

\begin{tabular}{|c|c|c|c|}
\hline & $\begin{array}{l}\text { Monomers, } \\
d_{4}^{25}\end{array}$ & $\begin{array}{l}\text { Polymers, } \\
d_{4}^{25}\end{array}$ & Volume change \\
\hline & $\mathrm{g} \mathrm{cm}^{-3}$ & $\mathrm{~g} \mathrm{~cm}^{-3}$ & $\%$ \\
\hline III & 1.211 & 1.220 & +0.1 \\
\hline IV & 1.258 & 1.258 & +0.1 \\
\hline $\mathbf{V}$ & 1.198 & 1.196 & +0.2 \\
\hline VI & 1.274 & 1.268 & +0.5 \\
\hline VII & 1.283 & 1.284 & -0.1 \\
\hline VIII & 1.200 & 1.200 & 0 \\
\hline
\end{tabular}
ortho ester structure 
crosslinking was found to be negligible, indicating there was almost no shrinkage.

It is known that curable materials undergo considerable shrinkage on crosslinking. The monomers prepared in this paper may be considered as the new materials for precision casting and high strength adhesives.

\section{REFERENCES}

1. T. Endo and W. J. Bailey, Makromol. Chem., 176,
2897 (1975).

2. T. Endo and W. J. Bailey, J. Polym. Sci., Polym. Chem. Ed., 14, 1735 (1976).

3. T. Endo and W. J. Bailey, Makromol. Chem., 177, 3231 (1976).

4. T. Endo and W. J. Bailey, J. Polym. Sci., Polym. Lett. Ed., 13, 193 (1975).

5. T. Endo, K. Saigo, and W. J. Bailey, J. Polym. Sci., Polym. Lett. Ed., 18, 457 (1980).

6. T. Endo, M. Okawara, and W. J. Bailey, Polym. J., 13, 715 (1981). 